DÁvid Gabriella

PhD-hallgató

Oktatási szakjogász, nemzetiségi vezető szaktanácsadó
DOI: 10.15170/DIKE.2018.02.01.08

\title{
Német nemzetiségi oktatás - kisebbségpolitika az Osztrák-Magyar Monarchia felbomlásától 1945-ig
}

\section{German Minority Education - Minority Policy from the Fall of Austro-Hungarian Empire to 1945}

Besides the military defeat, the fall of the Austro-Hungarian Empire was also due to the nationalist movements. In October 1918 Mibály Károlyi formed the Hungarian government and in November the new Ministry of Religion and Public Education launched its programme of how to make profound changes in the public education. Education became compulsory till the age of 14 and education was free. Gradual consolidation in the early 1920s was facilitated by vicomt Kunó Klebelsberg, the head of the national cultural policy and public education. In his opinion, culture was the major motive for further developement. In areas, inhabited by minorities, public schools were opened where education was provided in the language of the minority. Public elementary schools for minorities were provided in detail by Klebelsberg so that the schools would be suitable for the conditions of the dispersed minority.

Keywords: nationalities, education, minorities in Hungary, minority / ethnic monolingual education, bilingual education, public schools, German adult education

\section{Az előzmények}

Az Osztrák-Magyar Monarchia területe az I. világháború kitörése előtt hatszázhetvenhatezer négyzetkilométert, lakosságának a száma pedig 51 millió 300 ezer főt tett ki. Ez a több mint félszáz milliós népesség vallási szempontból hét, nyelvi-etnikai szempontból pedig tizenkét nagy csoportra oszlott. A nyelvi-etnikai csoportok közül egyetlen egy sem alkotott abszolút többséget. Legtöbben, csaknem 12 millióan a németek voltak, de az ő arányuk sem tett ki többet 24 \%-nál. A magyarok lélek- és arányszámban (10 millió, azaz $20 \%$ egyaránt a németek után következtek. A csehek aránya $13 \%$, a lengyeleké $10 \%$, az ukránoké $8 \%$, a románoké $6,5 \%$, a horvátoké $5 \%$, a szerbeké és a szlovákoké 4-4\%, a szlovéneké 2,5\%, az olaszoké 1,5\% volt. ${ }^{1}$ A zsidóság szétszórtan élt a birodalomban, sehol sem rendelkezett elkülönülő népességszigettel és a legkülönbözőbb népek (nemzetiségek) vették körül. Bár ezt a területi itegrálódást némely szerző önfeladásnak tekintette és az asszimilációhoz vezető útnak vélte, ${ }^{2}$ a Monarchia Lajtán túli és Lajtán inneni - koránt sem egységes szemléletű és életmódot folytató, valamint eltérő társadalmi beágyazottsággal rendelkező

\footnotetext{
${ }^{1}$ RoMsics, Trianon okai http://www.grotius.hu/doc/pub/UUYRSV/2010_122_romsics_ignac_trianon_okai.pdf

${ }^{2}$ ERÉNYI, Zsidóság a Monarchiában https://www.tankonyvtar.hu/hu/tartalom/historia/93-056/ch19.html
} 
- zsidóságának asszimilációs illetve disszimilációs hajlandóságát a területi szétszórtságon túl számos tényező alakította a 19. század második felében és a századforduló utáni évtizedekben is. ${ }^{3}$ Helyzetük ezért, amennyiben elfogadjuk, hogy magyar zsidók politikai és polgári jogegyenlősítésérôl szóló 1867. évi XVII. tc. után sem csupán vallást, hanem származást is jelent, ${ }^{4}$ a nemzeti kisebbségek helyzetével nehezen összehasonlítható.

A Monarchia népei körében tovább élő és erősödő föderatív törekvések a századfordulótól a birodalmi vezetést és az osztrák állam német pártjait is fokozottan foglalkoztatták. Egyre nyilvánvalóbbá vált, hogy a dualista konstrukció hosszabb távon, a modern nacionalizmusok korában nem alkalmas egy sokvallású és soknemzetiségű állam hatékony múködtetésére. Az 1867es osztrák nemzetiségi törvény elismerte az ún. néptörzsek egyenjogúságát, ${ }^{5}$ és a nemzetiségek egyenjogúságát deklarálták az 1868. évi XLIV. tc-ben hazánkban is. ${ }^{6}$ A 19 . századi magyar közbeszédben a zsidó és az izraelita kifejezés felváltva, következetlenül szerepelt. Ezzel szemben a vallási alapú megközelítés, az izraelita kifejezés tudatos használata jellemezte a jogforrásokat és az asszimiláció irányába elkötelezett magyar-zsidó történészek munkáit ${ }^{7}$ is, akik - az uralkodó neológ felfogásnak megfelelően - a Mózes-vallású magyarok felekezetéről írtak, nem pedig a magyarországi zsidók történetéről. A hivatalos felfogás (a statisztikai hivatalok) tehát és a társadalom többségének szemlélete - példa erre a kor szépirodalmának túlnyomó része - a zsidóságot hazánkban nem tekintette nemzeti kisebbségnek, ellentétben Kelet-Európa több országával. Általában az a felfogás dominált, hogy a zsidóság a nagy kötőerôt jelentő vallás által meghatározott etnikai csoport, amely fenntarthatja - főleg megreformált, ún. neológ formában vallását, saját kulturális értékeit, de ezekkel együtt is asszimilálódhat a nem zsidó (német-osztrák, magyar stb.) társadalomba. Ez a felfogás, amelyet többek között Sigmund Freud is vallott, kettős identitást tételezett fel. A magyar politikai vezetôréteg úgy vélte, hogy az effajta asszimiláció a magyarság pozícióit erősíti (erôsítette is) a soknemzetiségű Magyarországon ${ }^{8}$, és Ausztriát illetően hasonlóan vélekedtek az osztrák liberálisok is. A 20. század elején azonban új folyamatok indultak. A Csehországban élő zsidók jelentős része már cseh nemzetiségűnek, a másik jelentôs ún. zsidó centrumban, Triesztben és környékén élők olasznak és - ami a legmeglepőbb - a német-jiddis nyelven beszélő galíciai zsidók mintegy 90 \%-a lengyelnek jegyeztette be magát.

Az Osztrák Császárságtól eltérően (amely a tartományi partikularizmusnak hagyományosan teret biztosított) a Magyar Királyság a 16. századig egységes állam volt, és ehhez, a magyar elit 1867 után is ragaszkodott. Ebből következett, hogy miközben nemzetiségi törvényünk fajra, nyelvre és vallásra való tekintet nélkül az ország minden állampolgárát egyenlő jogokkal ruházta fel, sőt egyházi és iskolai téren a kulturális autonómia számos elemét is biztosította a nemzetiségek

\footnotetext{
${ }^{3}$ Lásd hozzá elsősorban GERŐ, A zsidó szempont; HANÁK, A lezáratlan per; 450-461.; HeLLER, A „zsidókérdés” megoldhatatlansága; KARÁDY, Önazonosítás, sorsválasztás; MCCAGG, Jewish Nobles and Geniuses in Modern Hungary 18-19.; MEYER, Jüdische Identität in der Moderne; SZALAI, A hazai zsidóság magyarosodása 216-223.; VAJDA, Ki a zsidó Közép-Európában 648-655.

4 Vö. SCHWEITZER, Gondolatok a magyarországi zsidóság első emancipációja kapcsán 55-65.

${ }^{5}$ BRAUNEDER, Osztrák alkotmánytörténet 193-228.

${ }^{6}$ Lásd bővebben NAGY, Linguistic legistlation 229-245.

${ }^{7}$ Lásd többek között BERGL, Geschichte der ungarischen Juden; LÖW, Aphorismen über die Geschichte der Israeliten in Ungarn; KOHN, Héber kútforrások.

8 A dualizmus-kori politikai érvelést ehhez lásd HeRGER, Polgári állam és egyházi autonómia 185-213.
} 
számára ${ }^{9}$, addig politikai nemzetként, azaz egyenjogú államalkotó partnerként nem ismerte el őket. A nemzetiségek által már 1848-ban is követelt területi autonómia biztosítását a magyar kormány mereven elutasította, és nemcsak a törvényhozás és a kormányzat, hanem idővel a közigazgatás csaknem kizárólagos nyelvévé is a magyart tette. ${ }^{10} \mathrm{Az}$ oktatás területén ugyancsak törekedett a magyar nyelv terjesztésére és a nemzetiségi nyelvek visszaszorítására.

A legfelsőbb vezetésből mindenekelőtt a trónörökös, Ferenc Ferdinánd tervezte a birodalom mélyreható strukturális reformját. Múhelyének, az ún. Belvedere-körnek a tagjai a Monarchia nemzeti elvű föderális átalakítására törekedtek. A Ferenc Ferdinánd és Ferenc József halála után trónra lépő IV. Károly 1918 májusában megállapodást kötött II. Vilmos német uralkodóval arról, hogy az osztrákmagyar hadsereget alárendeli a német vezetésnek. Mivel a Monarchia kompenzációs szerepe ezzel megszúnt, a soknemzetiségú állam megítélése az antant hatalmak között jelentősen romlott, és 1918 tavaszától egyre inkább a Monarchia felbontását támogatták több kisebb, jobban irányítható államra. Ezt a tervet jelentősen segítette az a tény, hogy a Monarchia etnikailag rendkívül megosztott volt. Egyre erősödtek a nemzetiségek körében a szeparatista nézetek, és a birodalom egész területén megszületett az igény nemzetállamok létrehozására.

1918. április 18-án a nemzetiségek kongresszust tartottak Rómában, ahol kimondták, hogy nem szándékoznak a Monarchia keretei közt élni. ${ }^{11}$ Kidolgozták az elszakadás programját, és mivel az antant már támogatta törekvéseiket, az álláspontok közeledtek egymáshoz. A magyar belpolitikában a kiegyezés után is megmaradt függetlenségi törekvések szintén nem erōsítették a dualista államot. IV. Károly utolsó kísérlete a Monarchia megmentésére az 1918. október 16-i császári manifesztum volt, amelyet a következő nap a Wiener Zeitung különszámában ${ }^{12}$ tettek közzé. A császár a Monarchiát szövetségi állammá nyilvánította azzal, hogy Ciszlajtánia „minden néptörzse” hozza létre nemzeti tanácsainak vezetésével a saját nemzeti államát. A nemzetiségek már nem érték be ennyivel, és teljes önállóságot kívántak. ${ }^{13}$ A Monarchia létének tehát az első világháborús katonai vereség mellett a nemzetiségi mozgalmak felerősödése vetett véget. Kérdéses volt azonban, hogy ezt az örökséget az utódállamok, Magyarország, Ausztria, Csehszlovákia, Lengyelország, Románia, Olaszország és Jugoszlávia továbbviszi-e vagy hatékonyabb nemzetiségi politikát alakít ki.

1918 októberében Károlyi Mibály vezetésével alakult meg a magyar kormány, majd novemberben az új Vallás- és Közoktatásügyi Minisztérium közzétette a közoktatás gyökeres átalakításának programját. Az iskolakötelezettség korhatárát 14 éves korra emelték fel, és a képzést ingyenessé tették. Az egyházi iskolákban működő tanítók, tanárok fizetését és nyugdíát egyenlővé tették az állami iskolák tanítóinak, tanárainak juttatásaival.

1919. március 21-étől, a Tanácsköztársaság idején a közoktatásügyi minisztérium ügykörét és a tanügy irányítását is a Közoktatásügyi Népbiztosság vette át. 1919. március végén megtörtént az állam és az egyház szétválasztása. Ennek következményeként az egyházi vagyon, így a nem állami oktatási-nevelési intézmények is állami tulajdonba kerültek. Megkezdték az új, egységes oktatásügyi

\footnotetext{
${ }^{9}$ NIKLAI, Oktatáspolitika 59-94.

${ }^{10}$ NAGY, A nemzetiségi törvény 70-74. és NAGY, Linguistic Legislation 229-245.

${ }^{11}$ HARMAT, Nemzetiségek http://tortenelemcikkek.hu/node/222

12 A manifesztum szövegét lásd a Wiener Zeitung 1918. október 17-i 240. számában: http://anno.onb.ac.at/cgicontent $/$ anno?aid $=$ wrz\&datum $=19181017 \&$ seite $=17 \& z o o m=33$

${ }^{13}$ Lásd továbbá NECK, Österreich im Jahre 191864 ff.
} 
intézmények kiépítését. Az óvodai nevelést minden 3-6 éves gyermek számára biztosítani kívánták. Nyolcosztályos egységes, kötelező és ingyenes állami népiskolákat akartak létrehozni, ahová a 6-14 éves korosztály jár. Négy évfolyamos szakiskolákat és öt évfolyamos középiskolákat terveztek. A felsőoktatást oly módon kívánták átszervezni, hogy a tanítóképzést főiskolai szintre emelik. Eltörölték az osztályozást, a vizsgákat, az érettségit, de az egyetemekre való bejutást felvételi vizsgához kötötték. Az elképzelések nagy része azonban csupán terv maradt, mivel a tanácsrendszer 1919. augusztus 1 -jén megbukott.

1919. augusztus 10-én az újjáalakult Vallás- és Közoktatásügyi Minisztérium a Tanácsköztársaság minden közoktatásügyi rendelkezését hatályon kívül helyezte, majd országszerte fegyelmi bizottságok vonták felelősségre azokat a pedagógusokat, akik szimpatizáltak a proletárdiktatúra művelődéspolitikájával. ${ }^{14}$

\section{A magyar közoktatás Trianon után}

1920. június 4-i trianoni békediktátumnak számos súlyos következménye volt a magyar közoktatásra nézve. Az elcsatolt területeken, azaz az 1920 előtti Magyarország kétharmad részén ott maradt a népiskolák kétharmada is, valamint a középiskolák mintegy fele. A következő évtizedek közoktatás- és művelődéspolitikáját elsősorban a revízió követelése és a keresztény-nemzeti ideológia alakította.

Az 1920-as évek elején a fokozatos konszolidációt nagymértékben elősegítette, hogy a hazai kultúrpolitika és a közoktatásügy irányítása gróf Klebelsberg Kunó kezébe került, aki a kultúrát tartotta a fejlődés elsődleges mozgatórugójának. ${ }^{15}$ Kultúrpolitikájában nagy súlyt kaptak a nép mûvelődését szolgáló és a közoktatást fejlesztő intézkedések. Vallás- és közoktatásügyi miniszterként (1922 1931) számos, a hazai közoktatásügy szervezeti és tartalmi átalakítását célzó reformot vezetett be. Ekkor zajlott le a magyar közoktatás történetének egyik legnagyobb szabású átalakítása, amely ezekben az években már halaszthatatlanná vált. A legfőbb feladat a hazai iskolarendszer belső szerkezetének modernizálása volt. A dualizmus korában számos új iskolatípus jött létre, de az új igények nyomán ismét újfajta iskolák létrehozása vált időszerűvé, mindezeket pedig egységes rendszerbe kellett szervezni. Emellett mindegyik iskolatípusban szükségessé vált a tananyag tartalmának korszerúsítése is. Klebelsberg iskolareformjának és kultúrpolitikájának elvi alapja a kulturnacionalizmus elmélete volt. Klebelsberg szerint a vesztes világháború, a forradalmak, a trianoni békediktátum mind hozzájárultak ahhoz, hogy hazánk politikai tekintélye csökkent, gazdasága tönkrement, jövője bizonytalanná vált, a lakosság hite, önbizalma szertefoszlott. Ebben a helyzetben a felemelkedés felé egyetlen út vezet: egy újszerű nemzeti érzés kibontakoztatása az emberekben, melynek alapja az a felismerés, hogy a magyarság nem rendelkezik számottevő nyersanyagkészlettel, gazdasági erőforrásokkal, de hatalmas kulturális értékek birtokában van. Időtálló értékű kultúránk egy magas szintű, korszerű oktatási és művelődési intézményrendszer keretei között jelentős további értékeket hozhat létre. Az ország felemelkedésének fontos tényezője tehát a kultúra minél szélesebb rétegekre való kiterjesztése. Ebből a sajátos nemzetnevelési

\footnotetext{
14 BÁRDI, Magyarország és a magyar kisebbségek 52-59.

15 Lásd bővebben NÉMETH, Iskolaügy http://mek.oszk.hu/01800/01893/html/11.htm és GLATZ, Konzervatív reform - kultúrpolitika 5-26.
} 
programból következett, hogy a magyar művelődés egész intézményrendszerét modernizálni, fejleszteni szükséges. Klebelsberg reformja az iskolarendszer egészére kiterjedt, a népiskoláktól az egyetemig. Az 1921. évi XXX. tc. a tankötelezettséget a 6. életév betöltése után következő 9 tanévben (6 év elemi és 3 év továbbképző, illetve ismétlő népiskola) állapította meg.

Klebelsberg kultúrpolitikai elképzelései között fontos helyet foglalt el a magyar nép múveltségi színvonalának emelése, amit a népiskolák tömeges felállításával és a szervezett népmúvelés kiépítésével kívánt megvalósítani. Kezdeményezésére 1925-ben nagyszabású népiskolai program indult. Az elemi népiskolák 1925 májusában megjelent új, a korszerű európai reformpedagógiai törekvéseket érvényesítő tanterve szerint a népiskola célja az volt, hogy a hazának vallásosan és öntudatosan hazafias polgárokat neveljen, akik az általános műveltség alapelemeit bírják, és képesek arra, hogy ismeretüket a gyakorlati életben értékesítsék. 1925-től adták ki az új tantervhez az „Egységes Népiskolai Veqérkönyvek” sorozatot, a népiskolai tantárgyak oktatását szolgáló tanítási kézikönyveket.

Az 1926. évi VII. tc. a mezőgazdasági népesség érdekeit szolgáló népiskolák felállitásáról és fenntartásáról rendelkezett. A törvény célja az volt, hogy létrejöjjenek az addig csak papíron meglévő 6-12 éves korig terjedő tankötelezettség tárgyi feltételei. Az országot $5 \mathrm{~km}$ sugarú körökre osztották, és kötelezték a hatóságokat vagy a földbirtokosokat a népiskolák felállítására. Az 1926. évi VI. tc. létrehozta az országos Népiskolai Építési Alapot, amelyből három év alatt ötezer falusi, tanyai tanterem épült Magyarországon egységes, korszerű típustervek szerint. A téglából, hatalmas ablakokkal, palatetővel, vörösfenyőből készült padlóval épült iskolákhoz háromszobás tanítói lakásokat építettek. A népiskolai építési akció megvalósítására 1932-ig 47.500.000 aranypengőt (az ország egyévi állami költségvetésének mintegy a felét) fordították.

A nemzetiségek lakta területeken ún. kisebbségi tanítási nyelvú népiskolákat hoztak létre. ${ }^{16}$ Klebelsberg miniszteri rendeletben részletesen szabályozta a kisebbségi elemi iskolákat, amelyek a magyar kormány becslése szerint jobban megfeleltek a szétszórtan élő kisebbségek adottságainak. A rendelet három különböző iskolatípust hozott létre. Az elsőben (A típus) minden tantárgyat a kisebbség nyelvén oktatnak, míg a magyar kötelező tantárgy. ${ }^{17}$ A másodikban (B típus) a tárgyak egy részét magyar nyelven, másik részét a kisebbség nyelvén, harmadik részét mindkét nyelven oktatják ${ }^{18}$, míg a harmadikban (C típus) minden tárgyat magyar nyelven oktatnak, csupán a kisebbségi nyelven való írás és olvasás kötelezô tantárgy. ${ }^{19}$

A statisztikai adatok szerint az 1928/29-es tanévben 48 A típusú, 98 B típusú és 314 C típusú iskola volt. A megfelelő értékeléshez szükséges a demográfiai kiindulópont figyelembevétele: az 1920-as népszámlálás szerint Magyarországon 325 abszolút német többségû település volt, amelyeket az A és B típus még együttesen sem fedett le. Ha azonban az iskolafenntartók alapján is különbséget teszünk, akkor világosan látszik, hogy nem is annyira az állam, hanem sokkal inkább a

\footnotetext{
${ }^{16}$ NAGY, Nyelvi jog és nyelvpolitika 112-124.

17 A mai egynyelvű nemzetiségi oktatás most is ugyanígy múködik, többek között Pécsett a Koch Valéria Iskolaközpontban az ún. egynyelvű osztályokban, ahol német nemzetiségi honismeretet is tanítanak heti egy órában.

${ }^{18} \mathrm{Ez}$ a rendszer a kétnyelvű nemzetiségi osztályokban él.

19 A Magyarországon élő bolgárok és görögök szombati illetve délutáni iskoláiban napjainkban is így zajlik a tanítás. Ezek az ún. nyelvoktató iskolák. Lásd az 17/2013. (III. 1.) EMMI rendelet a nemzetiségek óvodai és iskolai nevelésének irányelvéről, valamint VÁMOS, A kétnyelvű oktatás Magyarországon http://reald.mtak.hu/984/1/dc_1309_16_tezisek.pdf és BARTHA, Kétnyelvűség, oktatás 761-775.
} 
katolikus egyház volt az egyik legbuzgóbb asszimilációs intézmény. A protestáns felekezetű iskolák 90 \%-ában német nyelven adtak hittanoktatást, míg a katolikus iskolák között csak kétharmad volt az aránya azoknak az iskoláknak, ahol ezt a tárgyat anyanyelven oktatták. Összességében megállapítható az is, hogy az 1932-es évben a német származású iskolaköteles gyerekeknek kevesebb, mint 10 százaléka részesült $\mathrm{A}$ típusú iskolai oktatásban, kereken egy negyedük $\mathrm{B}$ típusú iskolában tanult, a nagytöbbség pedig arra kényszerült, hogy $\mathrm{C}$ típusú vagy akár magyar iskolába járjon. ${ }^{20}$

A Betblen-kormány nyomására Serédi Jusztinián György bíboros, hercegprímás (1884 - 1945) kimutatást készített a kisebbségi nyelv használatáról. Ebből kiderült, hogy a görög ortodox egyház iskoláiban majdnem kizárólag anyanyelven tanítottak, az evangélikus-lutheránus iskolákban és még a kálvinisták iskoláiban is széles körűen figyelembe vették a kisebbségeket, ha például az iskolás gyerekek többsége a német kisebbséghez tartozott. Ezzel szemben a német települések katolikus iskoláiban többségében magyar nyelven tanítottak. Ezek a hiányok nem csak a magyarosítási törekvésekre voltak visszavezethetők, hanem azoknak a tanítóknak a magas arányára is, akik egyáltalán nem tudtak németül vagy csak nagyon csekély nyelvi kompetenciával rendelkeztek. A tanárhiány enyhítésére a kultuszminisztérium néhány tanárképző intézetben továbbképző tanfolyamokat létesített és ezeket az 1929/30-as tanévben már 182 tanárjelölt látogatta. A szükségletet ebben az évben 1400-ra becsülték, ami több mint kilencvenszázalékos hiánynak felelt meg. 21

A polgári iskolákról szóló 1927. évi XII. tc. szabályozta a polgári iskolák szerveztét, felügyeletét és igazgatásának módját, valamint a iskolák létesítésének és fenntartásának módját. Korlenyomat, hogy az iskolatípus céljává tették, hogy a tanulót „vallásos, erkölcsös és nem zeti szellemben” gyakorlati irányú általános múveltséghez juttassa, és ezzel közvetlenül a gyakorlati életre vagy pedig a középfokú szakiskolákra előkészítse. Mind a fiú, mind a leány polgári iskolákat négyosztályossá tették és középfokú iskolává minősítették. A népiskola négy osztályának elvégzése után a tanulók 14-16\%-a iratkozott be a polgári iskolákba. A négyéves képzés itt gyakorlati jellegú volt, nem tekintették az iskola feladatának a tudományok rendszerébe és az elméleti gondolkodásba való bevezetést. A polgári fiúiskola rendes tárgyai között szerepelt $a$ ) hit- és erkölcstan, b) magyar nyelv, c) német nyelv, d) történelem, $e$ ) földrajz, f) számtan és mértan, könyvvitel, $g$ ) növénytan és állattan, b) ásványtan és vegytan, i) természettan, j) élet- és egészségtani ismeretek, k) közgazdasági és jogi ismeretek, l) mezőgazdasági és ipari ismeretek, m) ének, n) rajz, szépírás, o) testgyakorlás, p) kézimunka, míg a polgári leányiskola rendes tárgyai a következók voltak: a) hit- és erkölcstan, b) magyar nyelv, c) német nyelv, d) történelem, e) földrajz, f) számtan és mértan, g) növénytan és állattan, h) ásványtan és vegytan, i) természettan, j) élet- és egészségtani ismeretek, k) háztartási és nevelési ismeretek, l) rajz, m) szépírás, n) női kézimunka, o) ének, p) testgyakorlás. A polgári iskolákból csak tanító- és óvónőképzőkbe, valamint kereskedelmi és más jellegû szakiskolákba lehetett továbblépni. Gimnáziumba alig kerülhetett be polgári iskolát végzett tanuló, hiszen a különbözeti vizsga követelményeinek nehéz volt eleget tenni.

\footnotetext{
${ }^{20}$ KOLLEGA TARSOLY, Kultúrpolitika 461. http://mek.oszk.hu/02100/02185/html/1362.html

${ }^{21}$ Kollega TARSOLY, Kultúrpolitika 462-468. http://mek.oszk.hu/02100/02185/html/1362.html
} 
Az 1883-tól múködő gimnázium és a nyolcosztályos reáliskola mellett Klebelsberg minisztersége alatt új középiskola-típust, a reálgimnáziumokat állították fel az 1924. évi XI. tc. alapján. Mindhárom típus a népiskola négy osztályára épülő nyolcosztályos középszintű iskola volt, ahol a tanulmányok érettségi vizsgával zárultak. Az itt végzett tanulók bármelyik egyetemen vagy főiskolán folytathatták tanulmányaikat. Míg a gimnáziumokban tanították a klasszikus nyelveket (latin és görög), a reáliskolát a matematika és a természettudományok magas színvonalú oktatása jellemezte. A reálgimnázium új igényeket elégített ki. Itt modern nyelveket (angolt, franciát vagy olaszt) tanítottak a latin és a mindhárom iskolatípusban kötelező német mellett.

Az 1929/1930-as tanévben 28 gimnázium, 69 reálgimnázium és 23 reáliskola múködött hazánkban.22 A leány-középiskolák ügyét az 1926. évi XXIV. tc. rendezte, létrehozván a leánygimnáziumot és a leánylíceumot. A leánygimnáziumokban az általános kötelező tantárgyak mellett a latin és a modern nyelvek oktatására helyezték a hangsúlyt. Az itteni tanulmányok érettségi vizsgával zárultak, amely valamennyi felsőoktatási intézménybe való beiratkozásra jogosított. A leánylíceumokban a modern nyelvek, valamint az irodalmi és múvészeti tárgyak oktatását állították előtérbe. Latint csak rendkívüli tárgyként tanítottak.

Mivel a leánygimnáziumokba beiratkozott tanulóknak csak mintegy harmada kívánt később egyetemi tanulmányokat folytatni, ugyancsak az 1926. évi XXIV. törvénycikkel létrehoztak egy gyakorlati jellegú, mérsékelt tananyagú középiskolát, a leánykollégiumot, amelynek tantervében a nők számára szükséges alapvető ismereteket oktatták az általános múveltséget adó tárgyak mellett. Ez az iskolatípus nem honosodott meg, hiszen 1927-ben csupán két leánykollégium múködött Magyarországon, míg leánygimnáziumból nyolc, leánylíceumból pedig huszonöt.

1934-ben új középiskolai törvény született, amely egységes középiskolát teremtett (1934. évi XXI. tc.). Megszűnt a korábbi háromféle fiú- és háromféle leány-középiskola, az új egységes magyar középiskola a gimnázium lett. Az 1938-ban megjelent gimnáziumi tanterv az eddigieknél nagyobb teret szentelt az ún. nemzeti tárgyaknak (magyar nyelv és irodalom, múvészet, magyar történelem), és egyúttal csökkentette a görög és latin nyelv, valamint a természettudományi tárgyak óraszámát. A világtörténelem a korábbiakhoz képest kisebb súllyal szerepelt.

A középfokú szakoktatásról intézkedett az 1938. évi XIII. tc., amely a felső kereskedelmi, felső mezőgazdasági és felső ipari szakiskolákat, gyakorlati irányú középiskola” elnevezéssel középiskolává minősítette. Ezek a négy évfolyamos iskolák ettől kezdve érettségi bizonyítványt adtak, s a profiljuknak megfelelő felsőfokú tanulmányokra tették jogosulttá tanulóikat. A II. világháború miatt ezek a szakiskolák nem tudtak kellőképpen kifejlődni.

Hóman Bálint nevéhez füződik a tanügyigazgatás központosítását célzó 1935. évi VI. tc. megalkotása. A törvény szerint az állam felügyeleti joga az egyházi iskolákra is kiterjedt. Az iskolák feletti központi ellenőrzés a nemzetnevelés eszméjének az iskolai gyakorlatba való átültetését segítette elő. A népiskolai felügyeletről és a - vármegyék területével megegyező - népiskolai kerületekről is rendelkező törvény 1949-ig meghatározta a magyar tanügyi igazgatást.

Az 1920. évi XXV. tc. az egyetemekre és főiskolákra való beiratkozást szabályozta. Kimondta: a nemzethúség és az erkölcsi megbízhatóság mellett az egyetemre jelentkezőknél arra is figyelemmel kell lenni, „hogy az ország területén léteró" egyes népfajokhoz és nemzetiségekhez tartozó ifjak

22 NÉMETH, Iskolaügy http://mek.oszk.hu/01800/01893/html/11.htm\#Heading2 
arányszáma a hallgatók között lehetóleg elérje az illetö népfaj vagy nemzetiség arányszámát'. A numerus clausus hatására radikálisan csökkent az itt már nemzetiségek körébe sorolt zsidó hallgatók száma az egyetemeken. A korlátozást, a hallgatók nemzetiségi és faji alapon történő megkülönböztetését az 1928. évi XIV. tc. megszüntette.

A két világháború között 4 tudományegyetem mellett további 12 egyetem és egyetemi jellegű főiskola múködött hazánkban. A budapesti (1921-től Pázmány Péter Tudományegyetem néven), a debreceni (1921-tôl Tisza István Tudományegyetem néven) és a Trianon után Pozsonyból áttelepült pécsi, valamint a Kolozsvárról áttelepült szegedi tudományegyetemeknek jog- és államtudományi, hittudományi, bölcsészeti és orvostudományi fakultása volt. Budapesten működött az ország egyetlen műszaki egyeteme, a M. Kir. József Nádor Múszaki és Gazdaságtudományi Egyetem. Öt karon mérnöki és építészmérnöki, gépész- és vegyészmérnöki, mezőgazdasági és állatorvosi, közgazdaságtudományi, valamint a Sopronban múködő bánya-, kohó és erdőmérnöki karon folyt a műszaki szakemberek képzése. A felsőoktatás az 1930 - 1940-es években csak egy vékony réteg számára volt elérhető. Számos főiskola is képzett felsőfokon szakembereket ezekben az években. Működtek hittudományi főiskolák, jogakadémiák, gazdasági akadémiák, kereskedelmi, művészeti és katonai főiskolák. 1925-ben nyílt meg Budapesten a Magyar Testnevelési Főiskola.

A középiskolai tanárok képzésének kérdéseit 1924-ben szabályozták (1924. évi XXVII. tc.). A tudományegyetemek mellett tanárképző intézeteket hoztak létre. A négyéves képzés célja az volt, hogy a hallgatók az előadások és gyakorlatok során elsajátítsák a szaktárgyaik tanításához szükséges pedagógiai, pszichológiai és szakmódszertani ismereteket és készségeket. Ezenkívül a törvény egyéves tanítási gyakorlatot is előírt a tanárjelöltek számára. A középiskolai tanárképzés 1927-28ban életbe lépett új rendje és a tanárképző intézetek új szervezeti szabályzata lényegében 1949-ig érvényben maradt. 1939-ben Györffy István etnográfus, egyetemi tanár kezdeményezésére és támogatásával megalakult a Bolyai Kollégium, amely szegényparaszti származású főiskolai-egyetemi hallgatók demokratikus szellemű, bentlakásos intézménye volt. 1942-ben vezetősége alapszabályt dolgozott ki, amely autonóm vezetést, ügyintézést biztosított az intézmény számára. Ekkor vette fel a kollégium Györffy István nevét. Egyes kollégisták kapcsolatba kerültek a munkásmozgalommal illetve Parasztszövetséggel. 1944-ben a kollégiumot az állami szervek feloszlatták. ${ }^{23}$

\section{Német népművelés útjai 1920 és 1945 között}

A Magyarországi Német Népművelődési Egyesület számára gróf Bethlen István (1874 - 1946) miniszterelnök konszolidációs politikája teremtette meg a politikai keretfeltételeket 1921 és 1931 között. Az Erdélyből származó arisztokrata minden kisebbséggel szemben bizalmatlan volt, reálpolitikusként azonban világos volt számára, hogy a legfontosabb cél (a trianoni területvesztés revíziója) orientációváltást követel a kisebbségpolitikában. Mivel ez a cél meggyőződése szerint csak Németország segítségével volt elérhetô, a „német tényezô" mind befelé, mind kifelé való figyelembevétele megkerülhetetlen volt. Külpolitikai számításból Betblen olyan kisebbségpolitikát követett, amely tekintettel volt ugyan a kisebbségekre, de nem támogatta azokat. Ilyen okok miatt

\footnotetext{
${ }^{23}$ Lásd hozzá NÉMETH, Iskolaügy és pedagógia http://mek.oszk.hu/01800/01893/html/11.htm
} 
döntött úgy, hogy engedélyezi a német kultúregyesület felállítását, amelyet alkalmasnak tartott arra, hogy kifelé megértô kisebbségpolitikát demonstráljon. Ezen a ponton megfontolásai találkoztak Bleyer Jakab tervével, aki ebben a kérdésben, Betblentől eltérően, főleg a kultúra és az oktatás területen törekedett elsősorban arra, hogy javítsa az általa képviselt német kisebbség helyzetét. ${ }^{24}$

Bleyer német parasztcsalád gyermekeként Bácskában, Dunacsében született. Német népiskolai tanulmányai után a tehetséges fiú az újvidéki magyar gimnáziumba, majd a kalocsai jezsuita gimnáziumba járt. Ezt követően Budapesten folytatta tanulmányait germanisztika és magyar filológia szakon, ahol az Eötvös Kollégium tagja volt. 1897-ben szerzett bölcsészdoktori oklevelet: szakdolgozatát „A német történelmi népdalok magyar vonatkozásai 1551-ig” címmel készítette el. A magyar-német kapcsolatok témája ettől kezdve végig kísérte életét. 1905-ben, 31 éves korában habilitált, kilépett az állami szolgálatból, hogy egyetemi magántanárként a budapesti egyetemen oktasson. Már 1910-ben a Magyar Tudományos Akadémia levelező tagja lett, később pedig

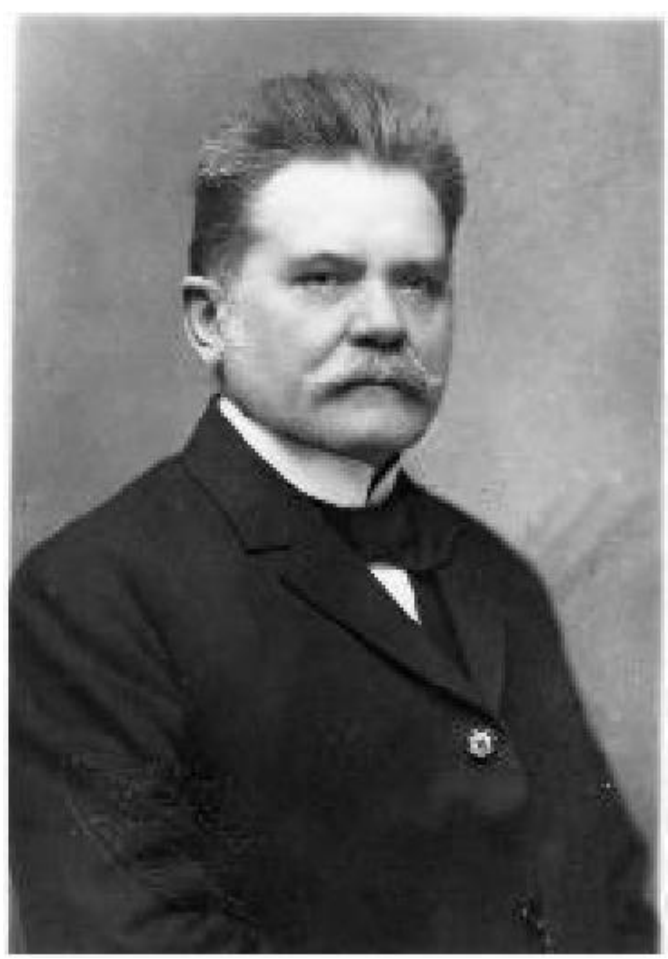
Németországban is hasonló megtiszteltetésben volt része, mint a müncheni Német Akadémia tanácsának tagja, valamint a tübingeni egyetemi tanács tiszteletbeli tagja. 1911-ben a budapesti egyetem hívására visszatért tanulmányai színhelyére, ahol a német irodalomtörténet tanára volt 1919 októberéig.

Bleyer 1915-től mint a magyarországi német kisebbség mozgalmainak egyik irányítója a politikai életben is részt vett. 1917-ben jelent meg programszerü tanulmánya „A magyarországi németség” címmel, amelyben kulturális jogokat követelt a sváboknak az 1868. évi liberális nemzetiségi törvényre hivatkozva. A Magyarországi Tanácsköztársaság alatt aktívan részt vett az ellenforradalomban, jelentős szerepe volt a Peindlkormány és vele a Tanácsköztársaság megbuktatásában.

1. kép: Bleyer Jakab (1874 - 1933)

(Forrás: http://bleyer.sulinet.hu/nevadonk/)

1920 után Magyarországon nem igen akadt olyan jelentős közéleti szereplő, aki számára a nemzetiségi kérdés megoldása ne fonódott volna össze a Magyarországot ért békediktátum következményeinek az orvoslásával. Ez a kettősség nem csak az államkoncepciókban volt tetten érhető, hanem a kormányzati szerkezetben is. A nemzetiségi kérdést kezdetben külön minisztérium kezelte, 1919 augusztusától 1920 decemberéig Bleyer irányításával, aki nemcsak germanista egyetemi tanárként, hanem a magyarországi németek egyik tekintélyes vezetőjeként is közismert volt. Miniszterként küzdött a nyugat-magyarországi német lakta területek Ausztriához csatolása ellen, ezáltal magára haragította az ausztriai és németországi német nemzeti érzelmúeket.

\footnotetext{
${ }^{24}$ GRÓSZ, Magyarországi német egyesületalapítás Trianon után http://www.archivnet.hu/politika/magyarorszagi_nemet_egyesuletalapitas_trianon_utan.html
} 
Bleyer a területi integritás híve volt, minisztériuma pedig nem csupán a kisebbségi kérdéssel foglalkozott. Feladatai közé tartozott a megfelelő propaganda kifejtése is kül- és belföldön egyaránt, annak érdekében, hogy a határok Magyarország számára minél kedvezőbben alakuljanak. Bleyer feladata abban állt, hogy a forradalmi időszak örökségét feldolgozza, annak törvényeit és rendeleteit hatályon kívül helyezze, és ennek ellenére nyújtson valami vonzót azoknak a kisebbségeknek, amelyek településterületüket le akarták választani a magyar államról.

Stílusosan Szent István napján, 1919. augusztus 20-án fogadták el és augusztus 21 -én hirdették ki a nemzeti kisebbségek egyenjogúságáról szóló rendeletet. Ezzel visszatértek az 1868. évi nemzetiségi törvény alapelveihez, amely csupán egyéni jogokat biztosított, kollektív jogokat nem. A kisebbségek formális jogot kaptak saját iskolák és egyesületek alapítására. A túlnyomórészt az egyházak által fenntartott népiskolákban azonban továbbra is az egyházi tisztségviselők határozták meg a tanítási nyelvet. Ezen túlmenően már Huszár Károly egy hónappal később hivatalba lépó kormánya is megállapította, hogy a rendeletet a közigazgatás szintjén általánosan elterjedt ellenállás miatt nem is tudták átültetni a gyakorlatba. Bleyer később aztán a már megszállt vagy elcsatolt területeken élő nemzetiségek megfigyelésére is vállalkozott. Mindebben meglehetősen kiterjedt és aránytalan intézményrendszer segítette. A minisztériumon belül minden nemzetiség számára - tehát a pár ezer fős ruszinoknak is - egy-egy főosztályt állítottak fel. Ezek mindegyike külön-külön elnöki, sajtó- és propagandaosztályra oszlott, külön segédhivatala és számvevősége volt. ${ }^{25}$

Bleyer, miután miniszteri múködését befejezte, 1921. január 1-jén alapította meg a ma is múködő Sonntagsblatt für das deutsche Volk in Ungarn c. folyóiratot, hogy fórumot teremtsen a kisebbség önszerveződéséhez. A Sonntagsblatt az ország egyetlen német nyelvű hetilapjaként rövid idő múlva a magyarországi németek fontos érdek- és jogi képviseleti orgánumává vált. ${ }^{26}$ Bleyerötezer előfizetőt tudott megnyerni a lapnak, leginkább falusi lakosság köréből. Célja volt, hogy világnézeti és vallási tekintetben tanítsa az embereket, hazafias szellemben a Trianon elleni revíziós propagandára neveljen, továbbá a német kultúrával és a német identitással kapcsolatos információkat a vidéki lakosság orvosi, gazdasági és jogi kérdésekben való tanácsadásával kösse össze. Újságjának ez a paternalista, antimodernista és kőkonzervatív irányultsága hangsúlyozottan politikamentes volt, és elkerült minden érdekorientációt.

1923. július 15-én Bleyer egyesületet alapított Ungarländischer Deutscher Volksbildungsverein (UDV, a továbbiakban: Népművelődési Egyesület) néven, amelynek haláláig vezetője maradt. Jóllehet ez a kulturális szervezet államilag engedélyezett volt, tevékenységét kormányzati és igazgatási szervek korlátozták. Így az egyesületnek 1933-ig 186 faluban mindössze 12.000 tagja volt, amely a magyarországi német lakosságnak csupán 2,5 százalékát tette ki. A kormány megtagadta a jogot a Népmúvelődési Egyesülettől arra, hogy iskolákat alapíthasson és tarthasson fenn. Ezért Bleyer arra kényszerült, hogy a kormánnyal folytatott hosszas tárgyalások útján érje el célját. A már említett 4800/1923. sz. június 21-i kormányrendelettel (amellyel átültették a közigazgatási gyakorlatba a trianoni békeszerződés kisebbségvédelmi záradékát) a miniszterelnök kötelezte magát, hogy garantálja a kisebbségi nyelvhasználatot a közigazgatásban, a sajtóban, a vallásgyakorlás

\footnotetext{
${ }^{25}$ FATA, Bleyer Jakab nemzetiségi koncepciója http:/ / epa.oszk.hu/00000/00036/00017/pdf/12.pdf

${ }^{26}$ EGRY, Nemzetiségpolitikák 97-112.
} 
terén, valamint az iskolákban és végül engedélyezte a nemzetiségi kultúregyesületek alapítását is Magyarországon, valamint a romániai Bánátban és a jugoszláviai Vajdaságban. Hivatalosan biztosították a szabad iskolaválasztást, a magániskolák létesítésének jogát, szülői kérésre, szülői értekezlet útján a kisebbségi nyelv, tanítási nyelvként való bevezetésének jogát, a kisebbségi tanárok képzésének jogát, legalább egy egyetemen kisebbségi nyelvi tanszék felállítását.

Bleyer még 1911-ben, Petz Gedeonnal alapította meg a budapesti egyetemen a Germanisztikai Intézetet. A következő évben disszertáció sorozatot indítottak a tudományos utánpótlás szorgalmazására. 1920-as évek végének jellemvonása volt, hogy a magyar közigazgatási, egyházi és iskolai hatóságok a kisebbségek nyelvi asszimilációját szorgalmazták a kormány új nyelvrendelete ellenére is, bár az garantálta a kisebbségek számára többek között az anyanyelv szabad használatát a közéletben és az iskolákban. ${ }^{27}$ Három héttel később, miután kiadták ezt a rendeletet, 1929-ben Bleyer újabb folyóiratot alapított Deutsch-Ungarische Heimatblätter címmel. Az 1933-ig negyedévenként megjelenő lap a magyarországi németség és a magyar-német kapcsolatok tudományos kutatását tűzte ki célul. Ehhez Bleyer magyarországi tudósok, kutatók mellett a Monarchia utódállamaiból és német nyelvű országokból is felkért szerzőket. Bleyer aktívan publikált is, miközben 1920-tól a Keresztény Nemzeti Egyesülés Pártja programjával nemzetgyúlési, 1926-tól pedig Egységes-párti országgyűlési képviselő volt. A magyar országgyűlés 1933. május 9-ei ülésén Bleyer keresztény konzervatív képviselőként a magyarországi német kisebbség érdekeiért szólalt fel, mellyel a nacionalista és jobboldali konzervatív körökben és a budapesti egyetemisták körében is uszító hadjáratot váltott ki saját személye és a magyarországi németek ellen.
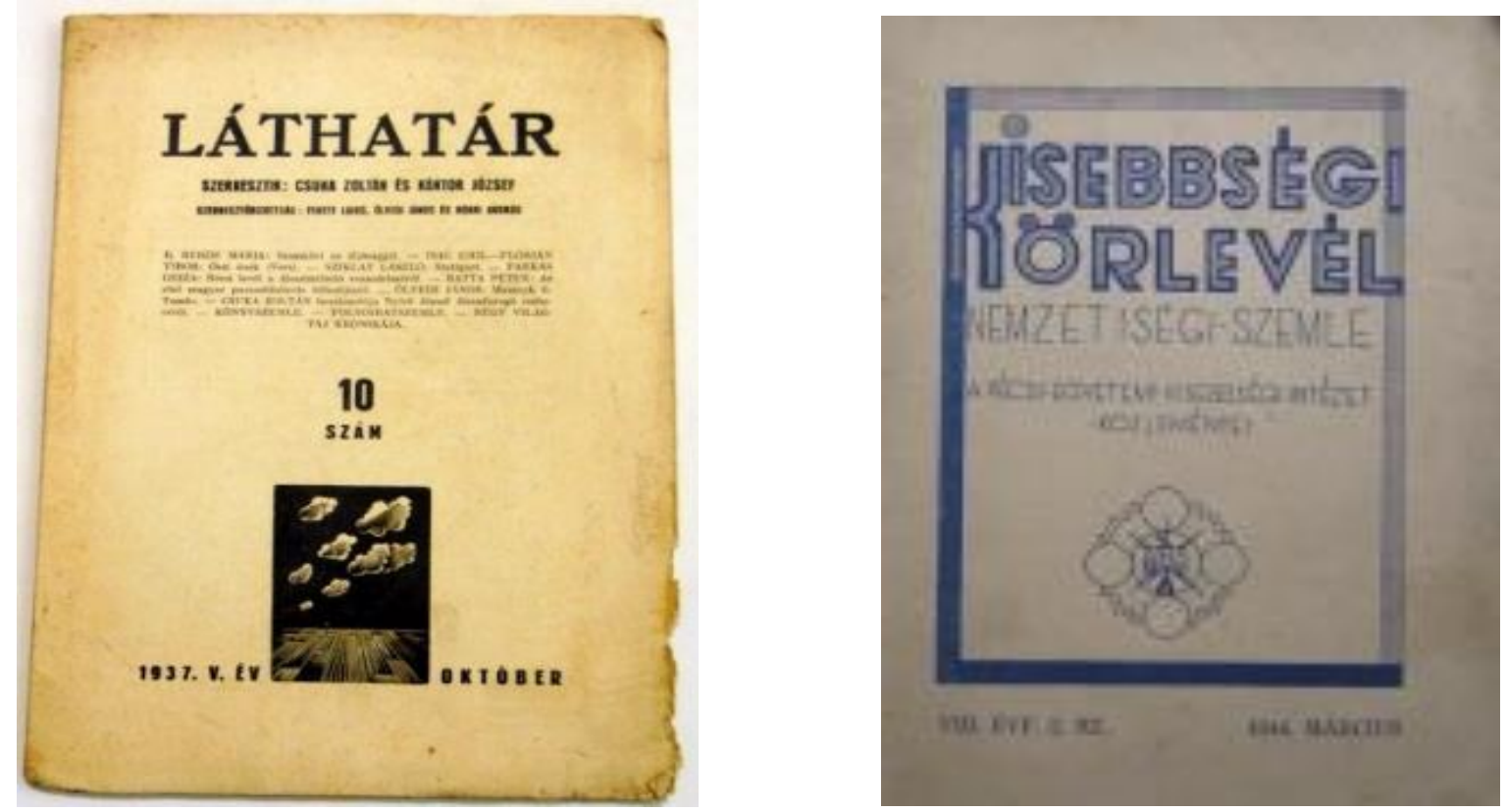

2. kép: A kisebbségi magyar irodalmi Láthatár $(1933$ - 1944) és a Pécsi Egyetemi Kisebbségi Intézet közleményeit tartalmazó Kisebbségi Körlevél (1942)

${ }^{27}$ NAGY, Nyelvi jog és nyelvpolitika 112-124. 
A kisebbségi ügyek 1933 után átkerültek a Miniszterelnökség III. ügyosztályából átalakított II. ügyosztályhoz. Ennek vezetóje Pataky Tibor lett, aki a külföldre szakadt magyar kisebbségek ügyében a külügyminisztériummal, a hazai kisebbségek ügyeiben a vallás- és közoktatásügyi minisztériummal múködött együtt. Pataky az ügyosztály rendelkezésére álló információkra alapozva szeretett volna általános szakpolitikai kezdeményezésekkel élni a minisztériumok felé is. Ebben azonban - legalábbis a magyar kisebbségek tekintetében - versenytársakra talált a Társadalmi Egyesületek Szervezetének Központja koordinálásával múködő félhivatalos szervezetekben, akik maguk is hasonló szándékkal léptek fel. Ez a konkurencia is oka lehetett annak, hogy Pataky elképzelése nem valósult meg, pontosabban a kormányzatnak egy tagolt, széleskörű intézményhálózatra kellett támaszkodnia (Államtudományi Intézet, a Külügyminisztérium főként követségeken dolgozó tisztviselői és a kisebbségi szakértők).

A korszak folyamán ez az intézményes hálózat mindjobban kiszélesedett, és végül az ügyosztállyal kapcsolatban álló szakintézmények köre felölelte a budapesti és pécsi egyetemek kisebbségekkel foglalkozó intézeteit, sajtópolitikája pedig olyan orgánumokra támaszkodhatott, mint a Láthatár, a Kisebbségi Körlevél valamint a Kisebbségvédelem, melyet a budapesti Kisebbségjogi Intézet adott ki.

\section{Felhasznált irodalom}

BÁRDI Nándor: Magyarország és a magyar kisebbségek az 1918 utáni első években. In: BÁRDI Nándor - FEDINEC Csilla - SZARKA László (szerk.): Kisebbségi magyar közösségek a 20. században. Budapest 2008, 52-59.

BARTHA Csilla: Kétnyelvűség, oktatás. Kétnyelvű oktatás és kisebbségek. Educatio 2001/9. sz. 761-775.

BARTHA Csilla: A kétnyelvűség alapkérdései: Beszélők és közösségek. Budapest 1999

BERGL, Josph: Geschichte der ungarischen Juden nach den besten Quellen bearbeitet. Leipzig 1879

BRAUnEDER, Wilhelm: Osztrák alkotmánytörténet napjainkig. Pécs 1994

ERÉNYI Tibor: Zsidóság a Monarchiában. https://www.tankonyvtar.hu/hu/tartalom/historia/93-056/ch19.html EGRY Gábor: Nemzetiségpolitikák Magyarországon 1919 - 1944. Nemzetiségi politika a két világháború között. Limes -Tudományos Szemle 2010/2. sz. 97-112.

FATA Márta: Bleyer Jakab nemzetiségi koncepciója és politikája (1917-1933). Regio - Kisebbség, politika, társadalom 1994/1.sz. http://epa.oszk.hu/00000/00036/00017/pdf/12.pdf (letöltve: 2018. július 1.)

GERŐ András: A zsidó szempont. Budapest 2005

GLATZ Ferenc: Konzervatív reform - kultúrpolitika. Gróf Klebelsberg konzervatív reformeszméi. In: Tudomány, kultúra, politika. Gróf Klebelsberg Kunó válogatott beszédei és írásai (1917-1932). Budapest 1990, 5-26.

GRÓsz András: Magyarországi német egyesületalapítás Trianon után.

http://www.archivnet.hu/politika/magyarorszagi_nemet_egyesuletalapitas_trianon_utan.html (letöltve: 2018. július 1.)

HANÁK Péter: A lezáratlan per. A zsidóság asszimilációja a Monarchiában. Jelenkor, 1983/5. sz. 450-461.

HARMAT Árpád Péter: Nemzetiségek a XIX. századi Magyarországon. http://tortenelemcikkek.hu/node/222

(letöltve: 2018. július 1.)

HELLER Ágnes: A ,zsidókérdés” megoldhatatlansága, avagy miért születtem hébernek, miért nem inkább négernek? Budapest 2004

HERGER Csabáné: Polgári állam és egyházi autonómia a 19. században. Budapest 2010

JÓBORU Magda: A köznevelés a Horthy korszakban. Budapest 1972

KARÁDY Viktor: Önazonosítás, sorsválasztás: a zsidó csoportazonosság történelmi alakváltozásai Magyarországon. Budapest 2000 
KARDOS József - KELEMEN Elemér: 1000 éves a magyar iskola, 996-1996 Budapest 1996

KISS József Mihály (Szerk.): Tanulmányok a magyar felsőoktatás XIX-XX. századi történetéből. Budapest 1991 KOHN Sámuel: Héber kútforrások és adatok Magyarország történetéhez. Budapest 1881

KOLLEGA TARSOLY István (szerk.): Magyarország a XX. században. Kultúrpolitika és közoktatásügy a két világháború között. V. kötet Szekszárd 2000 http://mek.oszk.hu/02100/02185/html/1362.html (letöltve: 2018. július 1.)

LÖW, Leopold: Aphorismen über die Geschichte der Israeliten in Ungarn. In: Allgemeine Zeitung des Judenthums 1839, nos. 94, 100., 1840, nos. 8, 12, 21.

MCCAGG, William O. Jr.: Jewish Nobles and Geniuses in Modern Hungary. New York 1972, 18-19.

MEYER, Michael A.: Jüdische Identität in der Moderne. Frankfur am Main 1992

MÉSZÁROS István: A magyar nevelés- és iskolatörténet kronológiája, 996-1996. Budapest 1996

NAGY Noémi: A nemzetiségi törvény kétes öröksége: Adalékok a dualizmuskori magyar nyelvjoghoz. Jogtörténeti Szemle 2017/3. sz. 70-74.

NAGY Noémi: Linguistic Legislation in Hungary during the Era of Dualism. In: WAKOUNIG, Marika - KÜHNEL, Ferdinand (szerk.): Central Europe (Re-)visited: A Multi-respective Approchach to a Region. Berlin - Bécs 2015, 229-245.

NAGY Noémi: Nyelvi jog és nyelvpolitika Magyarországon az első világháború végétől napjainkig. Közelítések 2015/3-4. sz. 112-124.

NAGY Sándor: Mába nyúló történelem. A harmincas évek pedagógiai irányai. Budapest 1988 NECK, Rudolf (szerk.): Österreich im Jahre 1918. Berichte und Dokumente. München 1968

NÉMETH András: Iskolaügy és pedagógia Magyarországon 1919 és 1945 között. In: PUKÁNSZKY Béla - NÉMETH András: Neveléstörténet. Budapest 1996 http://mek.oszk.hu/01800/01893/html/11.htm

NIKLAI Patrícia Dominika: Oktatáspolitika - egyházi érdekérvényesítés Ausztriában és Magyarországon a XIX. század második felében. Studia Iuvenum Iurisperitorum 2018/9. 59-94.

Romsics Ignác: Trianon okai.

http://www.grotius.hu/doc/pub/UUYRSV/2010_122_romsics_ignac_trianon_okai.pdf (letöltve: 2018. július 1.)

SCHWEITZER Gábor: Gondolatok a magyarországi zsidóság első emancipációja kapcsán (1848). In: BÁRDOS István BEKE Margit (szerk.): Egyházak a változó világban. Esztergom 1991, 55-65.

SEEWANN, Gerhard: A magyarországi németek története 1-2. Budapest 2015

SzALAI György: A hazai zsidóság magyarosodása 1849-ig. Világosság 1974/4. 216-223.

VAjDA Mihály: Ki a zsidó Közép-Európában? [Szekfű Gyula „Három nemzedék”-e kapcsán.]. Világosság 1989/8-9. 648-655.

VÁmos Ágnes: A kétnyelvű oktatás Magyarországon. Tannyelvpolitika, tannyelvpedagógia. Tézisek http://real-d.mtak.hu/984/1/dc_1309_16_tezisek.pdf (letöltve: 2018. július 1.) 